\title{
The Computer Utility: Competition or Regulation?
}

\author{
Manley R. Irwin $\dagger$
}

Observing "the growing convergence of computers and communications," 1 the Federal Communications Commission inaugurated a public investigation last November of the data processing industry. The traditional lines separating data processing and communications have been softened by the emergence of a new industry which, for lack of precise description, is known as the data, computer or information utility.

Within the decade, electronic data centers will provide computational power to the general public in a way somewhat analogous to today's distribution of electricity. Computer systems will blanket the United States, establishing an informational grid to permit the mass storage, processing, and consumption of a variety of data services: computer-aided instruction, medical information, marketing research, stock market information, airline and hotel reservations, banking by phoneto mention only a few. Many of these services already exist in embryonic form; and their growth prospects have received enormous impetus from recent developments in computer technology known as time-sharing or multiple access computer systems.

Time-sharing permits several users at remote locations to have access to or to share computer memory and logic capability.

Under the traditional batch processing method, access to the computer was limited to one user at a time, although even the most complex scientific problems consumed less than $10 \%$ of the computer's capacity. ${ }^{2}$ This kept data-processing charges high and limited the market for computer services. Multiple access computers make it possible to soak up this excess capacity. Indeed, computer power may experience such drastic cost reductions that it will be priced as low as, say, electricity.

$\dagger$ Associate Professor, Whittemore School of Business and Economics, University of Nicu Hampshire. Ph.D. 1969, Michigan State University. The research for this article was financed by a grant from the U.S. Office of Naval Rescarch. The victis cxpressed are those of the author.

1. In re Regulatory and Policy Problems Presented by the Interdependence of Computer and Communication Services and Facilities, FCC Notice of Inquiry, FCC 66-1001, Dkt. 16,979, 8 P \& F Radio REg. 2D 1567-68 (Nov. 9, 1960).

2. Computers are far superior in speed and memory power to any human user.

Typically, a computer will expend only a small fraction-usually less than 10 per cent

-of its base computing power upon even a complicated scientific problem. This waste

is more pronounced in business and data processing problems which require much less

usage of a computer's internal arithmetic and control registers.

C.EI.R., Inc., The Data Utility, July 28, 1965, at 5. 
What is the projected growth of computer utility services? The evidence tends to be fragmented. Some project that by 1970, sales of timcshared services will approach $21 / 2$ billion dollars; others assert that 75 per cent of all computers will possess time-shared capability by 1970 and by 1975, 90 per cent of all computers will be on-line; others project that within five years over 50 per cent of all computers will be tied directly into the nation's communications lines; and finally, still others maintain that, within the same time period, over half of the nation's communications will be transmitted as data rather than by voice. ${ }^{a}$ If the growth of the data utility approaches the estimated rate, it will bring the data processing and the communication industries into unprecedented intimacy.

\section{Market Structure}

Data processing firms can be classified as: (1) integrated firms that manufacture computers and peripheral devices and also offer data processing services; (2) nonintegrated firms that manufacture a variety of terminal equipment; (3) nonintegrated firms offering only data processing (service bureaus); and (4) corporations that sell data processing services as a sideline because of excess computer capacity.

The first group, computer manufacturers, includes some dozen hardware fabricators which also operate data processing centers or service bureau affiliates. These main-frame fabricators compete in a separate market with suppliers of peripheral hardware, such as desk-size computers, video display devices, printers, readers, data sets (modems), tape drives, and others.

The service bureau market is made up of firms that buy and lease computer hardware, and sell machine time or data processing to their subscribers. In contrast to the concentrated computer manufacturing market, about 800 firms engage in service bureau activities, suggesting

3. Address by Russell W. McFall, President, Western Union Telegraph Co., The Agc of the Communicator, before the Industrial Communications Association, in Montrcal, Canada, May 2, 1966, at 4: "It is estimated that less than 1 per cent of the 27,000 compliters in service today are linked in communications systems; more than half of the 50,000 computers expected to be in operation ten years from now will be in real-time operation in communications systems."

See also Address by Bernard Strassburg, Chief, Common Carrier Bureau of the FCG, The Communications Carriers and Management Information Systems, before the Institute on Management Information and Data Transfer Systems, at American University, Washing: ton, D.C., Oct. 21, 1965, at 2; Computer Time-Sharing goes on the Market, Business WeEk, Dec. 4, 1965, at 116; New Approaches to Random Access Files, 3 EDP ANALYzE, May 1965, at 1. 
that market entry into this phase of data processing is relatively easy." Many of these firms operate locally or regionally.

Finally, the data processing field is inhabited by firms whose activities are ancillary to data processing per se. These firms, having computerized their in-house data requirements, use up excess capacity and reduce overhead by expanding into commercial data processing. The banking and aerospace industries are particularly important in this sector of the market. ${ }^{5}$

Even the fully-integrated data processing firms lack the communications circuits that will be an essential part of a national information system. This makes the communications common carriers prime candidates for entry into the information utility field.

\section{The Communications Industry}

Two domestic communications carriers, Western Union and AT\&T, supply the nation's long distance communications channels and services. Of the two, Western Union has been more emphatic in committing its future to the information utility concept. ${ }^{\circ}$ Western Union already provides customized business information systems; it has established data processing service centers and computerized its switching net. In the near future, besides its present job-finding services, the company will offer computerized credit and securities ratings, library bibliographies, and medical data.

Although AT\&T has been content so far to lease communication lines without creating its own computer utility, it is clear that the telephone company would be a formidable candidate if it chose to enter the field. AT\&T possesses a nationwide network of communications circuits; it has introduced switching exchanges that operate automatically and have an information storage capability; it leases terminal devices-the Touch-tone telephone or Teletyperwriter units for transmitting and receiving data information. Through its Management

4. Diebold Group, Inc., Autonation: Impact and Iarplicitions, Focus on DevelopMENTS IN THE COMMUNICATIONS INDUSTRY 39 (1965) (for the Communications Workers of Am., AFL-CTO).

5. Menkhaus, At McDonnell, Computers are "Flying" High, Business Aurossatron, Feb. 1966 , at 33 .

For discussion of some of the problems incident to the banking industry and EDP sce Hearings on Legislation to Prohibit Banks from Peforming Cerlain Non-Banling Services and from Engaging in the Business of Personal Property Leasing Before the Subcomm. on Bank Supervision and Insurance of the House Comm. on Banking and Curreng, 89th Cong., 2d Sess. 121 (1966) (testimony of Herbert W. Robinson of ADAPSO).

6. WEStern UNION TeIEgRaph Co., 1965 ANNUAL REPORT 10. 
Information System the telephone company has computerized a host of internal management functions including customer accounts, records, credit, and payroll. All that remains for AT\&T to do is to introduce a digital information service comparable to that of Western Union.

\section{Competition Within the Computer Industry}

If we postpone consideration of IBM as a special case, the remaining major computer manufacturers generally inhabit two markets: manufacturing computer hardware and operating data processing centers competitive with those of independent service bureau firms. It is the existence of many independent service bureaus that gives the dataprocessing market a semblance of workable competition, but their survival is precarious in a market where size and integration are at a premium. Except for the companies that operate a service bureau as a sideline to use up excess capacity, the non-integrated firms must write off the full retail price of a computer with their service bureau revenues. The hardware manufacturers, using their own machines at a much reduced shadow price, can afford to operate on a smaller margin over variable costs. Similarly, the advantages of specialization attach, not to a firm that is small and local, but to a large company that can spread the costs of specialized software over a large volume of business.

Caught in a cost-price squeeze, the non-affiliated service firm may choose among several options: they could merge with a hardware supplier and become similarly integrated; play off one supplier's price against another's; merge into larger service bureau units in order to establish countervailing power, or get out of the industry altogether.

IBM is, of course, unique, not only because of its predominance as an integrated supplier, but also because it must live within the constraints of an antitrust consent decree. The 1956 decree ruled that the parent manufacturing firm could not engage in service bureau activities in which customer data is manipulated or otherwise changed. ${ }^{7}$ The decree

7. IBM threatens to continue and will continue said violations until the rclicf hereinafter prayed for in this complaint is granted. The aforesaid violations consist of: .. . (c) Restraining the development and growth of independent service burcaus in the United States.

Complaint, at 15-16, United States v. International Bus. Machs. Corp., Civil No. C72-814 (S.D.N.Y., filed Jan. 21, 1952). See also United States v. International Bus. Machs. Corp., 1956 Trade Cas. 71,117, 71,125 (S.D.N.Y., Jan. 25, 1966) (consent decree):

VIII(a) IBM is hereby ordered and directed to transfer, within one year after the date of the entry of this final Judgment, all its contracts for service bureau business to a corporation (herein-after called the Service Bureau Corporation), which may be wholly owned by IBM, and IBM shall thereafter be enjoined and restrained from engaging in 
sought to split IBM as a manufacturer and IBMI as a service bureau. To this end, the Justice Department required IBM to form the Service Bureau Corporation, a separate data processing affiliate, ${ }^{8}$ and run it as an independent business.

But the decree did not condemn IBM's own machines to idleness. Today, subscribers may bring their data to IBM's own data centers, process it, and be billed for the appropriate machine time. Because IBM does not "touch" customer data, the sale of raw machine time is ostensibly a legitimate activity under the consent judgment.

IBM not only manufactures time-shared computers, but operates time-shared data centers as well. With the Quicktran service, for example, IBM computer centers will offer facilities for solution of engineering and scientific problems by subscribers who are located at remote stations. In addition to its market information service, IBM recently inaugurated a time-shared service that edits, updates, and justifies correspondence, reports and other business documents. ${ }^{\circ}$ Again the user gains computer access via a remote terminal.

These new developments in technology and services raise the question, once again, of the status of IBM's consent decree. Does timesharing merely put IBM in the business of selling computer time over telephone lines or is IBM processing customer data for a fee? The answer to this question is not clear; but as if to hedge its short term antitrust bet, both the Service Bureau Corporation and IBM, the parent corporation, have recently introduced nationwide systems of time-shared computer centers. In the long run, however, IBM may find it necessary to convince the Justice Department ${ }^{10}$ that new technology has invalidated the distinction underlying its 1956 judgment.

\section{Competition Within the Communications Industry}

The Bell Telephone System, the nation's largest communication carrier, may be constrained by a consent decree from entering the data processing market. The agreement, which settled a seven-year-old antitrust suit, ${ }^{11}$ apparently forbids Bell to provide services that are not

the service bureau business except on a non-discriminatory basis for the Service Bureau Corporation and for service bureaus operated by other persons.

8. $I d$.

9. N.Y. Times, Sept. 9, 1966, at 64, col. 1 .

10. Service Bureau Corporation Plans National Computer System, 32 TelecossuuvicaTIONS REP., July 18, I966, at 28.

11. United States v. Western Elec. Co., 1956 Trade Cas. 71,134 (D.N.J., filed Jan. 14, $1949)$. 
subject to public regulation; ${ }^{\mathbf{1 2}}$ and there is as yet no government regulation of data processing.

Western Union is under no antitrust burden. As the telegraph company advances further into data processing; it has been conspicuously reluctant to file tariffs for these services. Such tariffs, once accepted by the Federal Communications Commission, carry a double edge. They would disclose rates on services which competitors in the computer industry could easily underbid; they would also extend data processing as a legitimate common carrier activity, thereby possibly opening the door for AT\&T to engage in like services. Indeed, Bell recently acknowledged before a House subcommittee that its entry into computerized services depended on the FGC's acceptance of a filed tariff. ${ }^{13}$

It is conceivable that eventually Bell as well as IBM may seek a variance from the Justice Department by pleading that changes in information technology have rendered the decree's sanctions obsolete. Bell may find it necessary to seek a redefinition of "communications" to include data processing on grounds that the two are inseparablea view reminiscent of its position that communication technology has blurred the distinction between voice and non-voice messages. ${ }^{14}$

12. Id. at 71,138 (consent decree, Jan. 24, 1956):

V. The defendant AT\&T is enjoined and restrained from engaging, either dircctly, or indirectly through its subsidiaries other than Western and Western's subsidiaries, in any business other than the furnishing of common carrier communications serviccs; provided, however, that this Section V shall not apply to (a) furnishing services or facilities for the plaintiff or any agency thereof, (b) experiments for the purpose of testing or developing new common carrier communications services, (c) furnishing circuits to other communications common carriers, (d) for a period of five (5) years from the date of this Final Judgment, leasing and maintaining facilities for private communications systems, the charges for which are not subject to public regulation, to persons who are lessees from defendants or their subsidiaries of such systems forty-five (45) days after the date of this Final Judgment, (e) directory advertising, (f) advice or assistance to other communications common carriers, or (g) businesses or services in. cidental to the furnishing by AT\&:T or such subsidiaries of common carrier communi. cations services.

13. Hearings on Activities of Regulatory and Enforcement Agencies Relating to Small Business Before Subcomm. No. 6 of the House Select Comm. on Small Business, 89th Cong., 2d Sess. 637 (1966).

14. In re American Tel. \& Tel. Co., 37 F.C.C. 1151, 1158-59 (1964):

The use by customers of leased circuits for alternate voice-record use is, with the $\mathrm{ex}$ ception of the defense agencies, a new service. It is in its infancy and we do not fecl that we should jeopardize the opportunity of the record carriers to provide such services by also allowing AT\&.T, with its huge resources, as compared with those of the record carriers, to compete with such carriers in providing the service.

See also Remarks by Frederick R. Kappel, Chairman of the Board of American Telephone \&: Telegraph Co., before the Institute of Electrical and Electronic Engincers, New York, N.Y., March 24, 1965, at 3:

Under these circumstances, I feel impelled to make a few comments to this audience on a recent suggestion that $I$ think would undermine the important role of the engincer in his drive for the sound, the practical, the genuinely needed. This suggestion com- 
If Bell succeeds in entering the data processing market, the corporation's integrated structure will give it competitive leverage that it presently exercises within the communications industry. Other companies must resort to Bell's circuits to provide communications services that compete with Bell's own voice service, and this puts them at the same disadvantage as the data processing centers that buy computers from manufacturers who also run service bureaus. So long as it costs Bell less on the margin to supply the circuits than it charges for them, Bell's retail subsidiary, in effect, receives a subsidy from its competitors. There have even been allegations that circuits are available to commercial users on more advantageous terms that to competing carriers. ${ }^{15}$ At present there is no way to police such discrimination, as Congress has been unwilling to give the FCC jurisdiction over carrier-to-carrier leasing agreements. ${ }^{16}$

Bell has another opportunity to exploit its control of communications channels at its competitors' expense, when it uses this capital equipment in two markets-one competitive (non-voice service), and the other a regulated monopoly (voice service). FCC regulation prevents Bell from setting prices as far above costs as its monopoly position would

bines all the worst features of putting the clock back, hampering if not frustrating the quest for understanding, and ignoring human needs. I am referring to the propozal that communication services to the public be arbitrarily divided into two clases, voice and nonvoice, and that these classes of service be provided by different entities with the telephone companies limited to providing voice communications only. On this proposal, I have consulted with several of my technical associates for whom I have profound respect. I find that to a man they are in a word, incredulous.

See also Bell's definition of communications and data processing taken from the Toronto Free Press, Sept. 10, 1966, in an ad from Bell of Canada: "Just call our Business Office and ask for the visit of a Communications Representative. He'll be available at jour convenience to help your EDP expert. After all-EDP is really communication. And communication is our business."

15. Western Union made this complaint during the FCC's telegraph investigation. Report of the Common Carrier Bureau of the FCC in the Domestic Telegraph Investigation, Dkt. 14,650 , at $156 \cdot 57$ (1965).

16. Hearings on H.R. 6018, H.R. S013, and H.R. 10270 Before the House Comm. on Interstate and Foreign Commerce, 88th Cong., 2d Sess. 86 (1964) (H.R. 6018 was a bill to amend section 203(a) of the Communications Act of 1934 as amended, with respect to the filing of schedules of charges by connecting carriers) (testimony of George L. Best, VicePresident of American Telephone \& Telegraph Company):

In our opinion, there is no need for this bill. The bill in question vould give the FCC broad new powers over communications common carriers in the area of private business arrangements regarding the furnishing of facilities by a carrier to other carriers. At the present time, the Commission has comprehensive powers to regulate carricrs in the traditional and appropriate area of service to the public. This bill goes far bejond that area. It would authorize a governmental agency to exercise control over an area that is traditionally and properly the area of private business management of a carricr's property. It would place the agency in a position of telling the cerriers the kind of business arrangements they should make between themselves even though what is involved is the furnishing of facilities by one carrier to another for use in the latter carricrs own business. We believe that there is no need for the grant of such sweeping new powers to the Commission. 
otherwise allow. But Bell can use the non-voice market to earn this extra profit by offering a customer a particular voice service at the regulated price only if it also uses Bell for its non-voice requirements. The competing non-voice carriers, which may offer a better service at a lower price, may still lose business to Bell.

Alternatively, Bell may choose to allocate an exaggerated share of capital equipment costs to the non-competitive service and thereby charge the monopoly price without offending the FCG. As a result Bell may charge less in the competitive market, where it has understated costs; and Bell's competitors suffer an incidental injury.

An ordinary firm in Bell's position would not want to charge less than the most profitable price in the competitive market, however it was pricing its monopoly service. But Bell operates under an over-all rate-of-return limitation, and its goal may be to achieve this return on the largest possible capital investment. This could give Bell an incentive to set an unprofitably low price in the competitive market, in order to justify the largest possible investment, and make up its allowable profits in the markets it monopolizes.

This pricing strategy is not without precedent. A study, undertaken by the Bell System at FCC request, assigned full cost to seven of Bell's interstate services. ${ }^{17}$ The study concluded that Bell's competitive services earned profits substantially less than generally regarded as compensatory by regulatory authorities. On the other hand, Bell's less competitive services earned in excess of reasonable returns.

\section{Competition Between Regulated and Nonregulated Firms}

Market rivalry is and will continue to be complicated by the structures of the industry candidates. As data processing inherits the competitive problems of the communications carriers, three problems are likely to be particularly important: (1) the availability of communications circuits; (2) the cost of communications circuits; and (3) the pricing of data utility services.

\section{The Availability of Communications Circuits}

Since the carriers own the nation's communications circuits, they have considerable influence over entry into the data utility market. The problem came before the FCC last year in a dispute between the

17. Report of the Common Carrier Bureau of the FCC in the Domestic Telegraph In* vestigation, Dkt. 14,650, at 156-57 (1965). 
Bunker-Ramo Corporation and the common carriers. ${ }^{18}$ Bunker-Ramo had recently added a message forwarding device to its stock information service. This capability permitted brokers in different locations to key into Bunker-Ramo's computer and virtually negotiate a stock transaction. In short, the computer suggested an analogy to a "switchboard."

Western Union refused altogether to lease circuits to Bunker-Ramo, on the grounds that the new service violated the authorized user section of their tariff. ${ }^{19}$ This provision allows circuits to be rented to customers who will use them for communication with its own customers or firms in the same business as the lessee. Western Union argued that BunkerRamo's service would exceed these limitations and place the lessee in the role of a full-fledged common carrier, transmitting messages between third parties. It was the interjection of this element-the element of third party communications-that prompted their concern that Bunker-Ramo's Telequote IV impinged upon common carrier activity.

18. Ultronic urges FCC to reject Bunker-Ramo "Telequote IP" Plea, 32 TELrcossuxiCATIONS REP., Jan. 24, 1966, at 18-19.

19. Letter from the Western Union Telegraph Co. to the FCC, Dec 3, 1965, at 2 :

It is clear that the extraction of the communications aspects from the proposed Tclequote IV service would destroy the concept of that service. What would be left would be another service.

In essence then, Bunker-Ramo proposes to use circuits leased by it from the common carriers to compete, on a resale basis, with the carriers for this business and to deprive them of the revenue being obtained therefrom. It is Western Union's position that the effectuation of the proposal would be unlawful and contrary to the public interest unless rendered by a common carrier.

As we understand the Telequote IV proposal, the service would be offered to the entire brokerage industry. The conclusion is inescapable, therefore, that under the proposal there would be a "holding out" to the general public as that term is used in the law of common carriage.

See also id. at 5 :

[I]t is our opinion that the proposed Telequote IV service offering would be in violation of various provisions found in Western Union tariff FCC No. 237. Section 3.2 of that tariff provides in pertinent part:

Only the following may be authorized users:

(a) Persons, firms or corporations who are to receive or send communications from or to the customer only and relating solely to the customer's business. .....

(c) Persons, firms or corporations in the same line of business as the customer. Banks security dealers and exchange brokers dealing in stocks, bonds or commodities shall be considered to be in the same line of business.

See also Letter from American Telephone \&. Telegraph Co. to the FCC, Sept. 29, 1965, at 2: Although these conclusions have some factual support in the material which accompanies the legal opinion, we are unable to conclude that the transmission of communications from one person to another is, or will remain, merely an incidental factor in Bunker-Ramo's plan. Indeed, it would appear that the transmission of communications is at the very heart of its proposal for "message switching" services, which services might prove, in fact, to be a most significant element of Telequote IV. The so-called "data processing" functions, to the extent that they exist at all in such cases, might be deemed ancillary to the transmission of communications and of subordinate importance. In such circumstances we believe a conclusion that Bunker-Ramo was not cngaging in a common carrier undertaking subject to regulation under the Communiations Act would be open to serious question. 
After several rounds of discussion and some give and take between the parties, however, Bell agreed to provide circuits under its "authorized user" practice. ${ }^{20}$

In principle, Bunker-Ramo was successful in this skirmish. But the confrontation between the data processing industry and the communications carriers points to a very real and fundamental question-the control over market entry exercised by the communications industry.

So long as common carriers with control over communications circuits have a plausible argument that a proposed service violates their authorized user tariff, data processing firms may be discouraged from extending their activities before the FCC has even had an opportunity to rule on the case. And the carriers' own plans for entering the data processing market give them an incentive to resist every attempt by an outsider to offer a data processing service that has elements of common carrier communications. If the FCC is to prevent the carriers from using its regulations to foreclose market entry, the Commission must either make it clear that communications services ancillary to data processing are outside its jurisdiction or else assume authority over computer utilities and begin regulating entrants from the data processing field.

\section{The Cost of Communications Circuits}

The market power that allows carriers controlling communications circuits to exclude prospective competitors can also be the basis for price discrimination which gives the carrier an advantage in the ultimate competition for data processing business.

On the data service side, the carrier supplies circuits to itself and to customers who operate their own data processing service. In the authorized user case, both the carrier and the firm selling to such users compete directly in the data/communications package. Whether the carrier is exploiting its market power over circuits or simply obtaining a reasonable rate of return by charging more than marginal cost, it is likely to give itself cost discounts denied to its competitor. Quite clearly these discounts would translate into a price advantage in selling computerized information services to the ultimate consumer.

The same costing advantage holds true if one shifts to the nonauthorized user case. Indeed it might become aggravated. The computer

20. Letter from Arnold \& Porter to Mr. Walter B. Kelley, Assistant Vice-President, American Telephone \& Telegraph Co., Feb. 4, 1966. 
firm sells only its data processing service; the subscriber to this service must turn to the carrier for necessary data circuits. In this case, the carrier will probably be able to offer a data/communications package, less expensive than if the subscriber has to add the retail price of communications channels on to his computer costs.

The peripheral equipment market cannot be ignored either. The Bell System not only supplies communication circuits, its vertical relationship with Western Electric gives it an important stake in manufacturing and leasing station equipment, notably Teletypewriter sets. If competition intensifies in the peripheral market, a tie-in of circuits and equipment will have the same advantage for Bell as a tie-in between voice and nonvoice services. The monopoly in circuits, which it finds difficult to exploit through high prices because of FCC regulation, can be exploited by tying a favorable contract for communications channels to a much less attractive equipment agreement. Or Bell may use circuit/ terminal equipment packages to spread its allowable rate of return over a large investment rate base. Indeed, there is some indication that the price of these combination services may be depressed sufficiently to place a burden on the carriers' customers in other markets. The FCC's telegraph investigation disclosed that Bell's TWX, which includes circuits and Teletypewriter sets, generated a 2.9 per cent return-a profit level generally regarded as unsatisfactory by both the communications industry and regulatory bodies. ${ }^{21}$

It would be misleading, on the other hand, to suggest that the dependence of data processing firms upon common carrier facilities is absolute. Computer firms may turn to private microrrave systems as links between data centers; and recently, the FCC has ruled that shared or cooperative use of privately orwned radio relay systems is permissible.22 But while this option may reduce costs per circuit mile, it requires a huge capital investment and the prohibition of interconnecting private circuits to the nation's public exchange network..23

21. Report of the Common Carrier Bureau of the FCC in the Domestic Telegraph Investigation, Dkt. 14,650, at 156-57 (1965).

22. In re Amendment of Parts 87, 89, 91, and 93 of the Commission's Rules, FCC 66 . 640, Dkt. 16,218, 7 P \& F RAdio REG. 2D 1713 (July 13, 1960).

23. Applicant's Proposed Findings of Fact and Conclusions before the FCC, In re American Tel. \& Tel. Co., Dkt. 14,251 (1962):

[T] he absence of interconnection with common carrier facilities is a factor which must be given very substantial weight when considering whether the entire bulk communications market is available to private microwave. Obviously, the inability to con. nect private systems with common carrier facilities is a highly signifiant fact-a fact which, in and of itself, would make it uneconomic for many users to build their own private systems. 


\section{Pricing of Data Utility Services}

The data processing industry and the communications common carriers possess mutual advantages in the pricing of time-shared data services-a third area of competition. Both industries may be able to split the data/communications package and assign price discounts as conditioned by market rivalry. EDP firms selling to authorized users, for example, cannot resell communications circuits at a markup over common carrier charges. Tariff schedules act, in short, as a price ceiling. There is no price floor in reselling communications circuits, on the other hand. The EDP firm could skip the charge for communications circuits and bill its customers only the EDP charge, thus relegating line costs as an overhead covered by some markets, but not by others. The ability to survive such loss leader pricing is as dependent on "deep pocket money" as on the ability to tap other profitable markets. In the non-authorized user case, where the EDP firm leases circuits to give customers access to a central computer, the user may find communication links subsidized by the firm selling the time-shared service. Apparently, this is the policy of General Electric's Medinet division: namely, that it will not bill line charges in tying hospitals to its computerized medical information centers. ${ }^{24}$ In supporting such pricing "deep pocket money" is a perfect substitute for the ability to tap other profitable markets; and if the large data processing firms were only competing with communications carriers, which have abundant financial resources of their own, subsidized circuit costs would be of no concern. But the firms that have so far given the data processing industry its competitive character are the small service bureaus that could not sustain a prolonged price war and operate at a disadvantage anyway by having to pay the full retail price for computers. They are likely to be real victims of unrestrained competition between the giant communications carriers and computer companies.

The communications common carriers may follow a converse pricing policy: absorbing the EDP component of the data/communications service while charging its subscribers full communications costs. Or the carrier may offer such severe price reductions to volume circuit users that this service, of necessity, must be carried by the firm's subscribers in other markets insulated from competition. The carriers' resort to price discrimination would not be a mere exercise of financial strength, because their regulated status gives them all the incentives prescribed 1,33 .

24. Coady, Nationwide Hospital EDP Slated for '67, Electronic News, July 18, 1966, at 
above to cut prices in competitive markets. This policy is especially tempting in the unregulated data processing market, where their pricing policies could escape the scrunity of the FCC. Western Union's diversification effort carries with it this latent possibility.

The further the carriers move into data processing, however, and the more suggestive their service becomes of a computer utility, the more likely it is that the FCC will begin to regulate at least certain segments of the data processing market. The question is: what form should this regulation assume?

\section{Public Regulation}

\section{The Direct Route}

Regulation of time-shared data services may come about directly or indirectly. In either case, the question of definition is likely to be crucial. What is the nature of data information transmitted between two points? Does such information constitute common carrier communications as defined in the Communications Act? What precisely is the nature of time-shared computer systems which incorporate message switching capability as well? Is this activity akin to public telephone or telegraph service?

If the FCG decides that these activities fall within its jurisdiction, then common carriers offering a data service will have to file appropriate tariffs or explain why they should not do so. This decision would meet head-on the question of whether the computer utility is to be a regulated industry, and the computer industry may find itself pleading that message processing and message switching stand as polar extremes, the former clearly outside the FCG's domain. ${ }^{20}$

25. See Letter from International Business Machines Corp. to the FCC, Feb. 15, 1965, at 2:

We believe the relevant legal standard that should guide the Commission is clearly set forth in Communications Act of 1934, as amended. Section 3 of the Act defines both wire and radio communications as "the transmission of writing, signs, signals, pictures and sounds of all kinds." This definition does not extend to the transformation of data or intelligence, at least for any purpose not directly contributing to the cfficient and accurate transmission of messages from one person or location to another. The transforming functions performed in the processing of data, such as analyzing, classifying. correlating, sorting, calculating, summarizing, producing records and reports, and constructing and applying formulae are not "transmission" and are thercfore not communication services within the meaning of the ACL.

The data processing business, like most other activities, often has significant incidental communications aspects, but this does not conrert the data processing to communications (emphasis added). 


\section{The Indirect Route}

Without planning to assume jurisdiction over data processing the FCG might find itself regulating the carriers' computer services anyway through a process of creeping regulations. First, a common carrier would file a tariff on its computer switching operation as a legitimate step in plant automation. Second, once computers are in place, memory units of stored information would be grafted to the switching system. A tariff would be filed and accepted on this service as a natural extension of computer capacity.

The indirect route may appear academic, but a recent tariff filed by an international carrier embodies at least the first step. ITT World Com, an international record (nonvoice) carrier, has recently submitted a tariff on a computer switching service. ${ }^{20}$ Customers are billed for service which routes messages to designated locations. The tariff does not include communications circuits. It does not include terminal apparatus. It does not embrace communications as a total service. Rather, ITT World Com has submitted a tariff solely on the computer and its switching capability.

What are the implications of FCC approval of ITT's new tariff? Does it mean that a computer manufacturer can no longer provide this service because it now falls into the common carrier bailiwick? Does it mean that any subsequent data processing service is a "natural" extension of

26. ITT World Communications Inc., Tariff FCC No. 54, Petition of the Western Union Tel. Co., June 8, 1966:

The statement in ITT's transmittal letter that the availability of the ARX "will climinate a customer's need to operate his own torn-tape relay center" makes clear that the underlying intent behind the proposal is to deprive a common carrier now providing service in the area of domestic operations of the revenues being received from that service. It is also reasonable to anticipate that from the standpoint of self-protection and competitive necessity, some or all of the other international carriers will be forced to offer a substantially similar type of service. Consequently, effectuation of the proposed ARX tariff can only serve to contribute further to the inroads which have becn made on Western Union's ability to carry out its obligations in the areas of its responsibility as a domestic carrier.

This was a petition of Western Union International for suspension. See also Rcply of ITT World Communications Inc. to petitions of the Western Union Tel. Co., Wesiern Union International Inc., and Collins Radio Co., June 16, 1966, at 6:

Western Union argues that because the ARX tariff may involve switching overseas messages, the tariff should be prohibited because of the general policy of separating domestic and international telegraph operations. We believe that such a proposal is against the public interest in that if adopted, a customer would forever be prevented from obtaining from a regulated carrier the benefits of an integrated switching system so long as there is any mixture of overseas and domestic message. ITT World Commu. nications' proposed service is designed to meet an existing need for fully automatic message switching and handling the traffic requirements of customers involved exten. sively in overseas business operations. Principally, the service will provide switching between the customer's overseas and U.S. offices; switching, if any, of messages between the customer's U.S. offices will be secondary. The tariff requires that each customer have at least one private line overseas channel connected to the switch it is controlling. 
the computer system and requires FCC approval? Will the carriers modify their foreign attachments rule? And do these decisions establish precedents that irretrievably lead to public regulation of the computer utility industry? Again the problem elicits more questions than answers.

\section{Competition as a Policy Alternative}

Perhaps there is a more fundamental question raised by the ITT World Com tariff. Does the computer utility as an industry fit the "natural monopoly" format that ultimately calls for regulation by the FGC? In the past the answer to this question usually depended on whether the computer utility satisfied several conditions which included a necessary and essential service to the community, a decreasing cost industry, and a high capital requirement incident to making such services available to the public. Although the evidence is at best tentative, some observations are appropriate, nevertheless.

\section{Nature of Services Offered}

If one posits a spectrum of information services, then presumably some services fall into the format of "natural monopoly," while others approach market diversity. For example, a medical information network consisting of hospital time-shared systems may not necessarily lend itself to duplication because of the feasibility of several medical units sharing only one system. Although several geographic regions might well accommodate different systems within each location, operating economies could limit the system to one firm, which would approach the analogy of the electric power industry. A recent study appears to generalize this conclusion for all data utility services. ${ }^{27}$

At the other end of the data service spectrum, stock quotations, airline reservations, credit ratings, legal services, marketing services, etc., are proliferating to the extent that diversity, specialization, and rivalry appears the rule. That scores of firms are entering the industry, offering competitive services, indicates computer utility firms possess none of the traits inherent in a regulated utility service, at least in the short run. ${ }^{23}$

27. D. Parkhiml, The Chaltenge of the Computer Utirity 148 (1960), concludes, "It has been one of the themes of this book that the time has now arrived when it becomes possible to consider computer power to be a likely candidate for admission to the publicutility club." See also Busness Auromation, May, 1967, at 68, quoting Rep. Cornelius Gallagher (Dem.-N.J.): "I feel we will have to have a need for gorernment regulation of the computer industry especially in the time sharing area."

28. The computer "utility" user is not restricted to doing business with any one com. pany. If you are not satisfed with your service, or are concerned about price, you can 


\section{Operating Costs}

The nature of operating costs will also be decisive in structuring the data utility industry. If there turns out to be a high ratio of fixed to variable costs over the entire relevant range, then lower unit costs will be realized if output is concentrated within the confines of a single firm. The information utility may experience decreasing costs, a condition that could lead to limited competition and eventual public regulation.

There is no guarantee, however, that data utility services as presently constituted will encounter decreasing operating cost despite the potential of sharing computer overhead. The reason is that (1) communications circuit costs vary directly with distance (band width and time), and (2) communication costs are becoming a greater proportion of total operating cost. The latter point is crucial. Recent studies indicate that some proposed computerized information systems split the EDP-communications cost about evenly; and the trend is for the communication segment to become dominant. ${ }^{29}$ Recent testimony before Congress argued that beyond 75-100 miles firms operating on-line, time-shared services cannot compete with customers who purchase business machines and operate data processing in-house. ${ }^{30}$ The limiting factor was declared to be the cost of leasing communications circuits.

Furthermore, there is little likelihood, at least in the short run, that the existing carriers can introduce substantial reductions in communica-

always "go" elsewhere. Similarly, any single computer installation is not forced to serve all potential customers on an equal basis. The big customer may expect preferential treatment, either in terms of price charged or speed of service. (Time-sharing systems have peak load problems where service delay times occur.)

In essence, then, computer "utilities" are not utilities.

P. Baran, The Coming Computer Utility-Laissez-Faire, Licensing or Regulation? 8.9 (1967).

29. A few years ago the cost of communication was only about 10 or 15 per cent of the total computer-communications system cost. In some of the larger systems now being considered, communications cost is 50 per cent or more of the total system cost. Estimates of over 60 per cent are anticipated for some later time-shared systems.

Id. at 18.

30. Hearings on Activities of Regulatory and Enforcement Agencies Relating to Small Business Before Subcomm. No. 6 of the House Select Comm. on Small Business, 89th Cong., 2d Sess. 351 (1966) (testimony of William Emmons, Keydata Corp.). See also In re Microwave Communications, Inc., F.C.C. 66R-182, Dkts. 16,509-19 (May 10, 1966).

The small business user hardest pressed by competition and therefore in most need of time-sharing computer service can afford to spend approximately $\$ 750$ to $\$ 1700$ pcr month for this service. He requires approximately 40 to 75 hours of connected com. puter time per month. At current rates this would amount to $\$ 600$ to $\$ 1125$ of computer utility service. A remote terminal costs between $\$ 100$ and $\$ 150$ per month, which leaves between $\$ 50$ and $\$ 425$ per month for communication cost. Another way of looking at the problem is to say that at current rates the economics of communication dictate how far away from the utility center the business may be.

Exhibit 4, The Economic Need for Common Carrier Microwave Communication as related to Time-Shared Comp. Utility Systems 7-8. (Prepared for Microwave Communications Inc. by Comm-Share, Inc., Ann Arbor, Mich., Oct. 20, 1966.) 
tions line cost given their investments in switching and transmission facilities-an investment that approaches 30 billion dollars. Two discount pricing attempts (the multiple channel and Telpak tariff) have been rejected by the FCC and the courts either on grounds of undue price discrimination, inadequate cost justification or lack of competitive necessity. ${ }^{31}$ Even communications satellite channels will probably be priced to average the cost of terrestrial and satellite circuits-as appears to be the case in international traffic-unless the FCC sees fit to encourage private noncommon carrier satellite systems for domestic use. ${ }^{32}$ In this context, it would be remiss not to mention the carriers' sensitivity to communication circuits not owned or controlled by the carriers. (Witness AT\&T's tepid reception to the Ford Foundation's satellite proposal, and outright opposition to private microwave. $)^{33}$ Thus, communication expenses may give the data utility a bias toward an increasing cost, and hence a competitive character, at least to the extent that time sharing systems attempt to expand beyond a single metropolitan area.

Rising communication costs may be a temporary phenomenon, however; and as in the case of General Electric, large diversified corporations could subsidize communications costs in the interim, tap distant markets and eliminate local firms before they have demonstrated superior economic efficiency. ${ }^{34}$ In this sense, cheap circuits or devices to share

31. In re American Tel. \& Tel. Co., 34 F.C.C. 217 (1963). See also In re American Tel. \& Tel. Co., 38 F.C.C. 370,380 (1964).

32. In re Authorized Entities and Users under the Communiations Satellite Act of 1962, FCC 66-677, Dkt. 16,058, at 21 (July 21, 1966):

We therefore conclude that only in unique or exceptional circumstances should noncarrier entities deal directly with ComSat. We believe that the ascertainment of such circumstances must be left to a case by case approach ....

See also In re Establishment of Domestic Non-Common Carrier Communiation-Satellite Facilities by Non-governmental Entities, FCC 66-207, Dkt. 16,495 (March 2, 1960).

35. In te Allocations of Frequencies, 27 F.C.C. 359 (1959). See 32 Telrcomaruxicatroxs REP., Aug. 22, 1966, at 24-25: "Another' 'fundamental" consideration in any appraisal of the Ford Foundation proposal," Mr. Hough (AT\&I) said, "is the cffect of its adoption on the general users of communications services or in short, the public." And he added, "We believe that only the most compelling public considerations would justify compromising the common approach to communications development. Fragmenting usage and diverting some of it to a specialized facility inevitably impairs efficiency." AT\&:T also quarrelled with the economic savings proposed by the Ford Foundation.

34. Coady, supra note 24, at 33. See also Recent Time-Shared Systems V'ery Successful,

GE Says, Electronic News, March 21, 1966, at 90. See also P. BARss, supra note 28, at 23: As the cost of communications will be expected to be the overriding consideration in many instances, merely by standing still we will allow a situation of dynamic instability to occur. This force will cause the larger computer utilities to grow larger as they service the entire nation economically; the smaller companies could compete only in a few major cities. The larger companies possess a sufficient cconomy of seale to serve to the disadvantage of the smaller companies.

Therefore, unless independent users and independent companies are permitted free access to concentrate their traffic, we could impede the development of the technology 
communication channel costs are particularly crucial to the survival of the small and medium-sized firm.

\section{Capital Costs}

The magnitude of capital outlays will be a third factor that will affect the choice between competition and regulated monopoly. This outlay is crucial, for the number of firms capable of providing data utility services will tend to be inversely related to the size of capital investment. These investment requirements can be categorized into hardware and software costs.

Hardware Costs. If we divide hardware into computer and terminal equipment, then a first question is whether the cost of large time-shared computer systems on the order of six million dollars automatically prevents market entry by the small or medium-sized firm. ${ }^{85}$ Two trends suggest that it may not. First, a service bureau company may lease rather than buy a computer, thereby spreading investment costs into a monthly stream of payments. (Leasing may persist if data processing equipment continues to become obsolete shortly after it is built.) Second, service bureau firms as well as others may rent machines indirectly from computer leasing firms whose monthly rates substantially undercut IBM's rates. ${ }^{30}$ Thus, the ability to lease shifts the burden of capital requirements back to the computer manufacturer and hence tends to remove a major deterrent to market entry for smaller firms.

Station equipment such as Teletype printers are much more of a problem for service bureau companies. If the information utility is to own both central computer and satellite terminal apparatus, as well as data transmission lines, then obviously the capital requirements of this investment effectively limit market participation to only the large firm. Indeed, the addition of manufacturing capability to leasing computers, lines and terminal apparatus approximates the organizational format of the Bell System. The policy implications of the computer utility adhering to this pattern are obvious.

On the other hand, there is no compelling reason why the customer must lease terminal input-output devices from the data utility. If the electric power industry is to be a (partially) borrowed model, then the

by placing a disproportionate advantage in the hands of the large computer companics at the expense of the smaller time-sharing supplier.

35. D. PARkHIL, supra note 27 , at 132 .

36. Bache \& Company, Progress Report, Levin-Townsend Computer Corporation, July 6, 1966. (The Government is now engaging in third party leasing to take advantage of lower leasing rates.) See Leasing of Computers Takes on New Glamour, Business WeEk, April 23, 1966 , at $70-74$. 
subscriber will own his own terminal apparatus, plugging his mobile device into sockets that connect to a data center. The RAND Corporation serves as such a prototype. This choice shifts a major investment burden to the subscriber and hence lowers the barriers to market entry to the data utility firm. In short, capital costs whether for main frame or terminal devices, although large, do not appear to be prohibitive.

Software Costs. Economies of scale and capital costs for software and system development depend entirely on the scope of the service being contemplated. On the low side, for example, "canned" programs can be purchased at rates that enable service bureau firms to handle computation, inventory control, invoicing, etc. A more expensive programming expenditure is typified by IBM's marketing service and input/output model. ${ }^{37}$ Although IBM used Department of Commerce data, conversion into computer language is estimated to have cost the firm in excess of two million dollars-an investment that would necessarily keep out many firms. ${ }^{38}$

Some services, such as a case law data bank, seem to be monopolies even on a national scale; and the only question is whether it is practical to require the company that controls the service to grant access to independent data processing firms. A more serious problem is software, such as educational programs, that lends itself to wide diffusion through independent time sharing systems and may, instead, be monopolized by the large hardware-software corporations being created by mergers between the electronics and publishing industries. ${ }^{59}$

\section{Conclusion and Evaluation}

There is much to be said for competition as a policy choice for the computer utility at least in the foreseeable future: most data services as they now unfold are characterized by diverse, specialized, competitive services; it is by no means clear that the industry will exhibit over-

37. Computers Zeto in on Industrial Market, 9 DAtA Processor, July 1966, at 11.

38. Francis, Computers Aid Market Analysis, Christian Science Monitor, Miay 17, 1986, at 14 , col. 1 .

39. Programming costs for, say, a national document retrieval system might exced the resources, not only of a single firm but of the entire data processing industry. In this cace, the government would be likely to bear the research and development cost-a possibility; that has prompted the President's Office of Science and Technology to include a Comsattype entity as a conceivable option. Hearings Before the Subcomm. on Science, Research and Development of the House Comm. On Science and Astronautics, 89th Cong., 1st Sess. 584 (1965) (testimony of Dr. William T. Knox). See also M. Flood, Commercial Information Processing Networks-Prospects and Problems in Perspective, in US. Nat'L Cousw'N ox Techinology, Autonation and Economic Progress, Techology and the Amendchin ECONOMY 233 (1966). 
whelming economies of scale; capital expenditures although potentially large do not appear to be a prohibitive factor in market entry. ${ }^{40}$

Nor is there any suggestion that the combined ownership of computer manufacturing, computer programming or communications circuits is essential to the optimum development of the computer utility. Computers can be leased; terminal devices can be purchased by the user; software can be acquired; circuits can be leased (or built); land and buildings can be rented.

Recitation of the elements identified with an open market environment does not, in itself, resolve the problems of entry, rivalry, or price discrimination, much less the issue of regulation. Yet public policy need not stand idly by until a market "shake out" narrows the choices. A short-term problem does exist which is vital and immediate to the competitive environment of computer utility operations-the cost of leasing telephone lines. It is not surprising that at this early date the communication problem has been discussed in terms of three alternatives:

(1) encourage government construction of a digital data network, separate and apart from the communication carriers' private systems,

(2) encourage the carriers (a) to accelerate the production of low-cost plant and facilities and (b) to modify tariffs, practices and customs encrusted with the tradition of telephone transmission,

(3) encourage the licensing of new common carriers, innovating the latest technical developments in switching, transmission and terminal apparatus.

Each alternative merits review.

There is a strong argument that a government data processing network would bring down computer costs and accelerate technical progress. ${ }^{41}$ But as a political proposition, the government network is a hopeless scheme. Until recently, federal agencies had difficulty operating microwave point-to-point communications systems-despite pro-

40. For additional arguments against regulation, see C. C. BARNETT, JR, AND Associates, THE FUTURE OF THE COMPUTER UTILITY 91 (1967).

41. Government ownership as a first option appeared in a report to the U.S. National Commission on Technology, Automation and Economic Progress. The report recommended:

(2) the federal government bring into being as rapidly as technology permits, at least one limited but major information processing network that is planned, developed, and operated to: (a) accelerate technological advance and gain experience in appraising economic and social benefits and costs of information networks; and (b) help meet a recognized unmet national need, such as for better information transfer through a national network of libraries and specialized information centers.

U.S. Nat'l Comm'n on Technology, Automation and Economic Progress, Techinology AND The AMERican Economy 252 (1966). 
nounced cost savings-because such ownership was thought to be inimical to a free enterprise economy. ${ }^{42}$

This leaves a second alternative of prodding the communications industry to increase both its rate of innovation and the speed with which new techniques become available to the general market. Investment decisions, it must be noted, are a prerogative of management. And in the exercise of this prerogative the carriers have been most reluctant to take advantage of either the investment tax credit or rapid amortization of plant. Here certainly is one point of departure. Perhnps the Federal Communications Commission could take a cue from the Federal Power Commission's decision to calculate electric utilities' investment return on the assumption that rapid amortization has occurred-whether the utilities elect this option or not.t3

A reevaluation of communication tariffs and practices is also possible. The grievance of the computer industry suggests several ways in which the rules of the communications industry could be made less of a burden for outsiders partaking of its services. Tariffs prohibiting customerprovided equipment could be liberalized, as could the restrictions on sharing communications circuits; cost discounts on leased circuits could be extended to small as well as large users; billing could be based on data information transmitted rather than on time elasped; and competitive bidding could be encouraged in the carriers' purchase of communication hardware. ${ }^{44}$

A third possibility is to make it easier to enter the communications industry. There are practical problems with this alternative. If a presumption of market entry is to be taken seriously, new applicants for certificates of convenience and necessity must overcome the heavy outlays necessary to survive the adjudicatory process; for inevitably a new applicant encounters the opposition of existing carriers who charge that new entrants are superfluous and technically incompetent, scavengers who will divide responsibility and threaten the economic health of the industry.

Deterrents to market entry are also embedded in the accounting practices of regulated entities. Because legal costs are a legitimate operating expense, the consumer subsidizes the carriers' resistance to market

42. See Irwin, The Communication Industry and the Policy of Competition, 14 BufFALO L. REV. 256 (1964).

43. N.Y. Times, Jan. 3, 1967, \& C, at 119, col. 4.

44. R. Mills, Communications Implications of the Project MIAC Mrultiple-Aecess Computer System, M.I.T. INSTITUTE of ElECTRICAL \& Electronic ENGiNeER, INTERNATIONil. CONVENTION RECORD 240 (1965). 
entry. One recent candidate has argued that free entry will become a workable presumption only when the public underwrites the legal costs incurred by the potential entrant. ${ }^{45}$

The growth of data processing has subjected both the restrictive practices and the technology of the communications industry to pressures that literally have no precedent. The FCC may be able to reduce circuit costs and improve carrier performance by the less drastic sorts of measures described above. Otherwise, a government data processing network may cease to be an unthinkable alternative.

45. Hearings on Activities of Regulatory and Enforcement Agencies Relating to Small Business Before Subcomm. No. 6 of the Fouse Select Comm. on Small Business, 89th Cong., 2d Sess. 366 (1966) (testimony of John Goeken, President, Microwave Communications, Inc.). 